\title{
Possible Reform for Chinese Governance on Anti-corruption
}

\author{
B. WANG, C.H. GU, T.T. LAI \\ PLA University of Science and Technology, Nanjing, China
}

ABSTRACT: Chinese anti-corruption system has played a significant role in anti-corruption affairs. However, the drawbacks of this anti-corruption system are obvious: (1) different punishments on similar corruption crimes; (2) governance exemplar in anti-corruption; (3) campaign-style anti-corruption instead of regular supervision; and (4) overlapping functions between anti-corruption agencies. The drawbacks above have led to somewhat inefficiency of Chinese anti-corruption, which should be studied in order to avoid the possible collapse of the system. Reasons leading to the drawbacks are analysized, which are regional disparity, cultural factor, and institutional factor. The reform for governance on anti-corruption is necessary. Firstly, there is a mismatch between governance and economy institutions. Secondly, effects of current anti-corruption policies are decreasing. Thirdly, the serious corruption will weaken the legitimacy of the CCP. According to the analysis on the current anti-corruption governance, four recommendations are given: (1) power supervision mechanism must be further improved; (2) the anti-corruption system should be further integrated; (3) standardization should be emphasized in the future to improve the governance of China; and (4) Rule by man should be changed to rule of law.

KEYWORD: Reform; Chinese governance; Anti-corruption

\section{CURRENT SITUATION OF CHINESE ANTI- CORRUPTION}

\subsection{Introduction to the Chinese anti-corruption system}

In China, the functional organization of anticorruption mainly consists of the Commission for Discipline Inspection of the CCP, state judicial organs, supervisory organs and auditing agencies of governments, and National Bureau of Corruption Prevention. The organizational structure of the Chinese anti-corruption system is shown as Chart 1 . Actually, the Chinese anti-corruption system is a multilevel and all-around system, in charge of corruption investigation, corruption prevention, and corruption crime punishment. It is noteworthy that the whole system consists of three sub-systems, which belong to the $\mathrm{CCP}$, the government, and the judicial system.

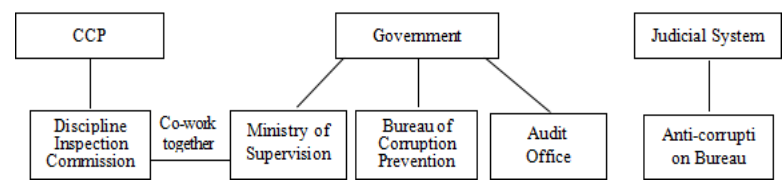

Fig 1. Organizational Structure of the Chinese Anti-corruption System

\subsection{Achievements of struggling against corruption}

The establishment of the Chinese anti-corruption system was in 1927, even earlier than that of the PRC, when the Discipline Inspection of the CCP was established. During the past decades, with the continuous development, this system has played a significant role in China.

1. Achievements in fighting against corruption crimes. From 2003 to 2009, 240 thousand pirating, bribery and corruption cases had been dealt by procuratorates. From 2005, when the special campaign against commercial bribery was launched, to 2009, over 69,200 cases of commercial bribery had been investigated and dealt with, involving 16.59 billion CNY in total.[1]

2. Improvement of the anti-corruption system. On one hand, as for the domestic corruption, the Chinese government has gradually strengthened the administrative accountability system, with the chief executive as the core, to fight against unjust law enforcement, administrative acts in violation of the law, disobeying orders and defying prohibitions, administrative inaction and chaos, earnestly fix responsibility for cases that seriously 
infringe on the interests of the state and the public and citizens' lawful rights and interests. On the other hand, as for the international cooperation in combating corruption, China acceded to the United Nations Convention against Corruption in 2005. In order to fulfill its obligations, China established an interdepartment coordination group consisting of 24 government departments to organize and coordinate the implementation of the Convention in China and the integration of Chinese laws and the Convention.

3. Satisfaction of the people. According to a survey by the National Bureau of Statistics of China, from 2003 to 2010, Chinese citizens' rate of satisfaction with the work of combating corruption and building a clean government rose steadily from $51.9 \%$ to $70.6 \%$, and the percentage of citizens who thought corruption had been kept down to varying extents increased from $68.1 \%$ to $83.8 \%$.[1]

\subsection{Disadvantages of the Chinese anti-corruption system}

However, the Chinese anti-corruption system has some drawbacks as follows:

1. Different punishments on similar corruption crimes. The measurement of penalty is determined by many other factors except for laws, which includes social impact, official position of criminals, attitudes of leaders, etc. Therefore, it is common in China that same crimes may get different punishments. For example, two criminals embezzling the same amount of money, one may be sentenced to death, while the other may be condemned to life imprisonment.

2. Governance exemplar in anti-corruption. In China, there are many incorrupt exemplars and also many corrupt exemplars propagandized by the government, which are the reflection and the necessary measure of exemplar governance in anti-corruption. Exemplar governance gives the authority too much discretionary power. On the whole, exemplar governance is not a modern one based on standardization, but a traditional one based on the rule of man.

3. Campaign-style anti-corruption instead of regular supervision. Actually, campaign-style governance is a comprehensive exemplar governance due to the rule of man, which is widely used in varieties of areas in China, including anti-corruption affairs. In a period, identified types or areas of corruption may be the emphasis of the anticorruption agency, while the others may be relatively ignored. The deficiency of regular supervision leads to the poor effectiveness of anti-corruptions. For instance, many people think that the criminals were punished due to bad luck.

4. Overlapping functions between anti-corruption agencies. Both in the central level and the local level, there are multiple anti-corruption agencies, belonging to the ruling party, the administrative system and judicial systems respectively. In practice, there is little cooperation between them because of the requirements of confidentiality during investigation. A negative result is that there are many areas ignored by all of these anticorruption agencies. In some cases, even an agency received the criminal clue, it could be ignored, because it is not their duties.

\section{ANALYSIS ON THE CHINESE ANTI- CORRUPTION GOVERNANCE}

There are several reasons leading to governance problems in anti-corruption.

\subsection{Regional disparity}

There are huge regional disparities in China. According to the World Bank estimates, China's income Gini coefficient far exceeds that of South Asian countries like India, Bangladesh, and Pakistan. Income differences in China are large both inter- and intra-regionally, with inter-regional differences increasing over time[3]. It is hard to give explicit and unified standard in different areas. Then, it is easy to understand why regulations in China were "relatively vague" and "there are not much that can be relied on as reference"[4]. In practice, leaders of the government often determine the extent of regulatory enforcement, including anti-corruption affairs. It is based on leaders rather than rules. It also leads to different punishments on similar corruption crimes.

\subsection{Cultural factor}

Confucianism plays a key role in Chinese traditional culture. From a century B.C to the early $20^{\text {th }}$ century, Confucianism had been the official ideology in China, and had significant influence on Chinese culture. It properly met the need of the ancient society, which was based on moral principles and traditions. In comparison, standardization is the base stone of the modern western thought. The standard for Chinese people to judge a thing or a person is not so clear, and it relies more on the experience. In comparison, standardization is more emphasized by western people. Cultural factor is a key reason for the exemplar governance in anti-corruption, which possibly leads to the campaign-style governance in anti-corruption. 


\subsection{Institutional factor}

On one hand, the Chinese government has prominent status in the country, more like an omnipotent government, and has significant influence on almost every aspect of China. Many society resources are controlled by the Chinese government. On the other hand, as the base stone of the Chinese governance, the bureaucratic system is based on strict hierarchy, which gives the leader of the government too much discretionary power. Furthermore, the supervision on the leader is insufficient. For example, as the top leader of a province, the Secretary of Provincial Committee of CCP has the power on most officials' appointment, including the officials in the anticorruption system. As a result, the power of leaders of the government control many resources, with a lack of supervision. It is likely to lead to the abuse of power and corruption.

Bo Xilai case can be used to explain the problems more clearly. Bo Xilai is the former top leader of Chongqing local government. Bo's governance style named as "Chongqing Mode" was actually a comprehensive exemplar governance, using campaign-style governance. It inevitably leads to the abuse of power and corruption. Chongqing Mode was severely criticized by then-prime minister Wen Jiabao as “a disaster of governance”（文革遗毒）. Later, Bo was condemned to life imprisonment for the abuse of power and corruption by the court.

\section{NECESSITY OF REFORM FOR GOVERNANCE ON ANTI-CORRUPTION}

\subsection{Mismatch between governance and economy institutions}

Since 1978, China has experienced a great change in economy. Just after the infamous "cultural revolution" (1966-1976), China's economy almost collapsed. But now, China has the second largest GDP across the world. It is the free market and international trade that have liberated economic resources and have allowed Chinese to create great fortunes. If we look at the development of China in the past 30 years, we can clearly see the step-by-step liberation of economic institutions in the fields of agriculture, industry and international trade, and their positive effects on China's economy. For example, in the early 1980s, the most serious problem was lack of crops to feed the large population. At that time, farming land belonged to the local communities of farmers rather than individual farmers. Farmers had to work as a group and were paid almost the same no matter how much they contributed to the crops. Under such institutions, most farmers were not active in doing their job, which led to the poor productivity of crops. The government then decided to let farmers have their own individual land and also allow them to sell their crops to the free markets. By this way, the crop yields began to increase.

With the improvement of economic institutions, China's economy becomes more prosperous and efficient. But compared with the free economy, the governance pattern of China has almost remained unchanged during those years. It is highly undemocratic, authoritative and centralized. This governance model has its advantages and disadvantages. In the situation of emergency (e.g. war or earthquake), this model is useful in mobilizing all available resources to deal with the crisis. Even after 1978, in the era of opening and renovation, CCP still used this governance pattern to promote the renovation in modern agriculture, industrialization, urbanization and export strategy. But the disadvantages have become more serious than ever. The power of governance is highly controlled by individual officials, e.g. those officials in high positions of powerful agencies such as oil departments. Also in the 2000 counties in rural areas of China, the governors of the counties are like dictators in their territories like Bo Xilai.

CCP should change their governance pattern by limiting and monitoring the power given to the government officials. Only in this way could the free economy be protected from corruption and become sustainable.

\subsection{Decreasing effects of current anti-corruption policies}

The whole society is involved in corruption. People from western countries may not understand how serious the corruption is in today's China. For example, when a Chinese man's wife is ready to give birth, he has to give bribes to doctors and nurses in the hospital. When his kid goes to school, he has to give gifts to teachers. If he works in the government, sometimes, he has to give gifts to his boss if he wants to get an important position.

Some institutions easily cause corruption. For example, the "Hukou" (residence permission) policy divides the population into two groups, the group living in cities with good public services, and the group living in rural areas without competent public services. Esp. the "Hukou" of big cities, such as Beijing and Shanghai, is much more valuable. The large disparity of public services between cities and rural areas encourages people to try their best to get the "Hukou" of big cities, even if they have to give bribes to concerned powerful men. This institution actually makes big room for corruption. More seriously, some officials and public staff even influence institutions and public policies for the chances to get bribes. The train services are always in shortage for most Chinese. But the reason is not always the shortage of transportation ability, but the lack of transparency when tickets are sold. 
Interest groups benefit from corruption. Since 2000 , under the policy of essential economic sectors being controlled and managed by state-owned companies, many large state-owned companies have become powerful and influential. In the sectors of finance, electricity, nuclear power, oil and communication, those state-owned companies become monopolies and earn their interests easily. The managers and staff in these companies are well paid and some even have the chance to support private business run by their families. To keep their advantages, these people spend lots of money in bribing the government officials who are in charge of monitoring the state-owned companies. They even deliberately give good positions of the state-owned companies to the families of powerful officials. In this way, interest groups have developed and they are certainly obstacles to any renovation that may reduce their illegal benefits.

Corruption exists in a continuous way. Since the beginning of renovation of China, all the leaders of CCP have paid great attention to the prevention of corruption, and the campaigns to reduce corruption have been implemented one after another. Though each year many corrupte officials and public staff are arrested and sent to prison, corruption seems never to be reduced as expected. There must be some problems with the governance and political institutions of China, which leads to the continuity of corruption in governments.

\subsection{Serious corruption will weaken the legitimacy of CCP}

When we look back at what happened in the late 1940s, one conclusion can be drawn that the corruption of the National Party (who was governing China at that time) was one of the major reasons that helped CCP defeat the National Party and gain the support of the majority. Today's CCP cannot become corrupt as the National Party in the 1940s. It could be expected that serious corruption will definitely reduce the support by the population and reduce CCP's legitimacy. Actually, the leaders of CCP have already realized this dangerous situation. The former Secretary General of CCP and the President of China, Mr. Hu Jintao, admitted that the failure of anti-corruption would cause the failure of CCP's governance[2].

\section{CONCLUSION}

1. Power supervision mechanism must be further improved. In short-term, the power supervision on leaders should be improved. Fortunately, it has been emphasized by the central government of China. More independent status has been entitled to the judicial system in recent years. After the
Third Plenary Session of the $18^{\text {th }}$ CPC Central Committee, the power of Discipline Inspection Commission has been enhanced. All of these efforts are beneficial to increase the power supervision.

2. Integrate the anti-corruption system. It is a shortto-medium-term recommendation. The current dispersive anti-corruption agencies should be integrated according to their functions. Overlapping functions must be avoided, which has been proved to lead to misconduct and evasiveness. An integrated anti-corruption organization may be established like ICAC (Hong Kong Independent Commission against Corruption) in the future.

3. Standardization should be emphasized in the future to improve the governance of China. In medium-term, standardization should be emphasized in the future to improve anticorruption governance. The laws and regulations of anti-corruption should be more explicit, and the phenomena of different punishments on similar corruption crimes should be eliminated. What is more important is that it will significantly influence the governance style of China. Standardization is an inevitable way for China to change from a traditional authoritarian government to a modern democratic government.

4. Rule by man should be changed to rule of law. In the long run, the radical resolution of problems in anti-corruption governance relies on the changing of the Chinese governance style. It should be a long way, and could be successful through reform step by step. However, it must be changed from rule by man to rule of law, without it, China cannot become a successful country in the future. During this long period, standardization is a key process leading to the changing of rule.

\section{REFERENCES}

[1] China's Efforts to Combat Corruption and Build a Clean Government. Information Office of the State Council The People's Republic of China. (Dec 2010), Beijing.

[2] Chris Wu. 2014. Hu Jintao acknowledges that a disqualified CCP will have to disappear from chinese history. http://chinascope.org/m/content/view/16/148/1/0/

[3] Huber.2006. Survey of Regional Inequalities in Transition Economies.

[4] W-H Yee. Transforming Rules-in-form into Rules-in-use: Voluntary Program, Exemplar and Regulatory Governance in China. Lee Kuan Yew School of Public Policy, NUS. 